\title{
Disability, Workplace Relations and Social Exclusion of "The People with Special Needs" in Selected Public Organisations in Ibadan, Nigeria
}

\author{
Samuel Ayodeji OMOLAWAL (PhD) \\ Temiloluwa Abigail OBISESAN
}

Department of Sociology

Faculty of the Social Sciences

University of Ibadan

Ibadan, Nigeria

\begin{abstract}
People with special needs constitute an important but special group that needs to be cared for by the society. However, this category of people continues to experience social exclusion and discrimination in the society as well as in the work place. This study investigated Perception towards Disability, Work-place Relations and Social Exclusion of the people with special needs in selected public organisations in Ibadan Metropolis. The study, anchored on the social model of disability theory, was conducted in public organisations in Ibadan metropolis, Nigeria. Study design was crosssectional survey. A total of 488 employees were selected using Cochran's 1977 formular. Instruments of data collection were questionnaire (460), In-Depth Interviews (20 officials), and Key Informant Interviews (8 employees living with disability). Quantitative data collected were descriptively analysed while qualitative data were content analysed. Findings revealed that there was poor compliance with legislations on employment of this category of people (84\%) and reasons given for their low number in government organisations included wrong perception that they cannot work effectively (16.4\%) and unavailability of supportive equipment (21\%). Also, eighty two percent (82\%) of the respondents were willing to have people with special needs as their colleagues at work and factors that can make respondents uncomfortable with people with special needs included not knowing how to relate with them (15.2\%) and sense of pity (29\%). Although government workplaces are not made conducive for the disabled, workers generally have positive attitudes to them. Government should enforce the implementation of relevant legislations to give more attention to issues of disability.
\end{abstract}

Keywords: Disability, Legislations, Social exclusion, Organisation, Discrimination

\section{Introduction}

Disability in the contemporary society has become a force that cannot be ignored due to the great effect it has on the society. Colin and Geof (2003) described disability as that which is equated with individual functional limitations or other defects. The disabled people, now more preferably referred to as people with special needs, people living with disabilities and physically challenged persons constitute a minority group, segregated from the larger society and discriminated against. Shakespeare and Watson (2002) described them as an oppressed group in the society. Lang and Upah (2008) described them as those that constitute one of the poorest, socially excluded and marginalized groups within the Nigerian society. People with special needs may constitute a few number, nevertheless, they represent a very significant group in the population. This set of people constitutes a special group to be cared for in a special manner in the society. According to Asiwe and Omiegbe (2014), the disabled refer to people with impairments (physically, sensory) and because of this impairment or disability cannot cope with regular school or class or organisation and methods without formal special education training. Other words used to describe disability include impairments, handicapped, crippled. However research has shown that though these words look the same, there is a difference between them.

The World Health Organisation (WHO, 1980) gave distinct definitions of the words impairment and disability. While impairment refers to any loss or abnormality of psychological, physiological or anatomical structure or function whether permanent or temporary, disability on the other hand refers to any restriction or lack (resulting from an impairment) of ability to perform an activity in the manner or within the range considered normal for a human being. Examples of impairment include any loss of sight, hearing, mobility or learning capacity. Impairment can be present at birth or result from accident or disease and is different from having a medical or health condition; for instance arthritis is a health condition whereas loss of dexterity is an impairment that can be caused by arthritis (British Social Attitudes Survey, 2009). In 1986, Michael Oliver, made a clear distinction between impairment and disability: 
While impairment refers to the functional limitation within individuals caused by physical, mental or sensory illness; disability refers to the loss or limitation of opportunity to take part in the normal life of the community on an equal level with others because of physical and social barriers. In other words, impairment is as a result of physical, sensory or mental illness, however it becomes disability when such an illness is causing limitation in the interaction with others and certain things cannot be done. While impairment may be biological, disability is socially constructed through discrimination and prejudice. According to him, for example, if the only means to enter a cinema is by using steps, then a person who has an impairment of using a wheelchair becomes disabled. Therefore disability derives from organizing society in such a way as to change impairment into disability (Haralambos \& Holborn, 2008).

Based on 2011 global population estimates, over a billion people, or about $15 \%$ of the world's population are estimated to live with some form of disability. In 2012, the World Health Organisation estimated that nearly 650 million people or $10 \%$ of the world population of about 6.5 billion people were moderately or severely disabled (World Report on Disability, 2011). In addition, based on the World Report on Disability (2011), approximately 25 million people in Nigeria live with one form of disability or the other with about 3.6 million of them having significant functional difficulties. Unfortunately, despite this high number, very little support is available to the subject; they are often excluded from social, economic and political matters (World Report on Disability, 2011). Some people deliberately do not relate with the physically challenged people because they feel they are the worst set of people. This therefore becomes a social vice as social relations become difficult. Also, because of the rejection they face, many people living with disabilities do not try to look for jobs in formal settings, thus increasing the level of poverty in the country (Lawal, 2016).

Howard and O'grady (2004) argued that people living with disabilities are the most socially excluded and most disadvantaged in the society. Rezaul, Nath and Sharmin (2011) defined social exclusion as relational which ruptures relationships between people and the society resulting in a lack of social participation, social protection, social integration and power. People living with disabilities in the society are regarded as second class citizens therefore excluded from mainstream activities. For persons with disabilities, social inclusion occurs in several contexts and covers nearly all aspects of life including infrastructural, interpersonal and personal levels (Hall, 2009). A culture of inclusion is a culture that promotes workforce integration and brings to life diversity potentials: where people with different backgrounds can work effectively together and perform to their highest potential (Pless and Maak, 2004). Most work places or organisations, however, lack this culture of inclusion especially in the context of this category of people in the society. The objectives of this study were therefore: to examine the extent to which people with special needs are excluded, preferred, or discriminated against in the workplace; and to investigate the nature of interpersonal relationship between this category of people and co-workers in selected public organisations in Ibadan, Nigeria.

\section{Social Exclusion}

According to DFID (2005), social exclusion is a process by which certain groups are systematically disadvantaged because they are discriminated against on the basis of their ethnicity, race, religion, sexual orientation, caste, descent, gender, age, disability, HIV status, migrant status or where they live. It is often associated with feelings of shame, fear and rejection both by the excluder and the excluded. Duffy (1995) and Klasen (1998) mentioned that social exclusion is concerned with not being able to participate effectively in economic, social, and cultural life and, in some characteristics, alienation and distance from mainstream society. Social exclusion inhibits the participation of the excluded group, such that they cannot participate freely. According to Silver (2007), social exclusion is a multidimensional process of progressive social rupture detaching groups and individuals from social relations and institutions and preventing them from full participation in the normal and normatively prescribed activities of the society in which they live.

Rezaul (2015) described social exclusion as a process which can involve the systematic denial of entitlements to resources and services, and the denial of the right to participate on equal terms in social relationships, in economic, social, cultural or political activities. A socially excluded group could not only participate freely in the society, but also are denied certain rights accrued to them.

Furthermore, Rezaul et al (2011) explained social exclusion as:

a) Multidimensional, encompassing social, political, cultural and economic dimensions and operating at different social levels.

b) Dynamic, impacting in different ways to various degrees at different social levels over time.

c) Relational, focuses on exclusion as the rupture of relationships between people and the society resulting in the lack of social participation, social protection, social integration and power. 
UNICEF (2006), in its report "Excluded \& Invisible" clearly defined social exclusion as a form of process of disability. Within the society, the disabled only do not actively participate in the activities on going; their rights also are infringed upon. Finklestein (1980) pointed out the social exclusion phases people living with disability go through. According to him, within each phase, the manner in which these people are socially included or excluded within contemporary society will differ. Several periods evolving pose different context of dealing with the disabled. For example, the period of agrarian feudalism which was before the European industrial revolution, because there were few people, mobility was limited, therefore, such a society did not preclude disabled people from active participation in their local communities. However, in the period of industrial revolution, people with disabilities were effectively excluded from being in paid employment, due to the fact that they were not able to maintain the pace set by the factory system. Consequently, physically challenged people were separated and thereby socially excluded from mainstream social and economic activities. Finkelstein maintained that during the third phase, which was just commencing, this category of people will experience their liberation from social oppression they hitherto faced. This will be achieved through physically challenged people and their allies working collaboratively to achieve commonly agreed goals, through the aegis of the disability movement.

The exclusion of these people in the society automatically contributes to their exclusion from the work place. Employers tend to exclude them from employment, promotion and other benefits of work, this is because they feel they are less efficient and not up to the tasks, however research has shown that the reverse is the case as according to Okoli (2013), they are reliable and trustworthy, they possess good work ethic, they are passionate and they have a positive attitude towards life and work and have a can-do spirit and are ready to go extra mile. In a study conducted by Carol (2002) - Barriers to employment for Disabled People, only four in ten employers believed that there would be benefits to the workplace from employing disabled people. It was also revealed that those working in large workplaces were more likely to identify benefits than those in smaller workplaces.

Under the Employment Equality Acts 1998 and 2004, employers are obliged to take appropriate measures so that these special people could have access to employment, participate in employment process and undergo training. Some of these measures include training resources, adaptations to the workplace premises to make them more accessible for workers with disabilities, provision of equipment for work, patterns of working time. However, there are so many great concerns among employers in relation to employing people living with disability; these include: perceived risks to productivity; worries over the implications of making workplace adjustments; lack of clarity over legislation and required practices, and negative perceptions of legislation (BSA, 2009). On the contrary to such concerns, according to ILO (2010), evidence suggests that employees with disabilities demonstrate increased productivity, lower accident rates, and higher job retention compared with the general workforce. Furthermore, People with special needs have often acquired heightened sensibilities and unique skills. They are natural problem solvers and have a remarkable ability to adapt, which enhances their potential to develop powerful business ideas and solutions. They are regarded as an untapped source of talent.

BSA (2009) revealed that while some employers did not consider there would be any difference in employing someone with either physical or mental health condition, other employers thought that a mental health condition would be more unpredictable and therefore harder to manage in the workplace. In support of this, the World Report on Disability (2011) revealed that most excluded from the labour market are often those with mental health difficulties or intellectual impairments. It further says people with more severe impairments experience greater disadvantage and ultimately exclusion. The more severe an impairment is, the less the rate of employment. Employers believe there are difficulties in employing people with poor health conditions because of the possibility that absences at short notice would affect work routines. Some employers do employ this category of persons based on the ability and consideration as regards their health condition. Many of them are prevented from working by the negative attitudes of others and not by their impairment alone. Their exclusion from labour and credit markets has a negative impact on the wider economy (DFID, 2007)

In the workplace, every employee looks forward to a harmonious and good working relationship with their colleagues. However, for the "disabled employee" (obvious form most especially), relationship with others could be another obstacle and hurdle to be faced. Included in work environment is the social interaction and interrelationship amongst workers in the work place, however as regards this, physically challenged people are found in the wrong work environment as most evidences show that interaction with co-workers is poor. In his book, stigma: The Experience of Disability (1966), Hunt argued that "the problem of disability lies not only in the impairment of function and its effects on us individually, but also more importantly in the area of our relationship with "normal people". A sharp dividing line is drawn between the social lives and interests of 'able-bodied' and people living with disability; the latter are 'set apart from the ordinary' because they pose a direct "challenge" to commonly held societal values 'as unfortunate, useless, different, oppressed and sick' 
In Nigeria, Section 6 of the Federal Military Decree 1993 states that "all employers of labour shall reserve for the disabled not less than $10 \%$ of the work force, at least $10 \%$ of all fund allocation to training and personal development shall be reserved by employers of labour for the disabled". Also it says that a disabled person shall not by reason be subjected to any disability or conditions by any employer. These however are only seen in the paper and not implemented at all. Not only have people with disabilities experienced unfair discrimination in the past, but they also continue to be the recipients of negative perceptions by employers, leading to continued discrimination against them and their marginalization in the labour market (Marumoagae, 2012).

\section{Theoretical Framework: Social Model of Disability Theory}

The social model arose in response to the critique of the medical model of disability which identifies disabled people as those individuals with physical, sensory and cognitive impairments as less than whole. This model is constructed and expressed in Marxist terms, and assumes that human nature, and the resultant choices that individuals can make for themselves, are determined by the structure and ideology of society. It is therefore argued that the kind of society in which disabled persons live has a profound effect upon how their disability is experienced and structured.

The Equality Act 1993, as a legislative tool, takes account of two main conceptual models of disability. The first of these is the medical model that focuses on impairment as the cause of disability preventing people from living a normal life; policy based on the medical model therefore relies on health care solutions to cure conditions, alleviate symptoms and mitigate impairment. The second conceptual model of disability is the social model that identifies systemic barriers, negative attitudes and deliberate or inadvertent exclusion as the key contributory factor in disabling people affecting their ability to carry out daily activities. It recognizes that individual functional limitation or impairment leads to disability mainly if society fails to take account of and include everyone regardless of their individual differences. Policy based on the social model therefore tries to address these societal failings instead of the medical form of those concerned (Barnes, 2012).

The social model disability theory is an attempt to switch the focus away from the functional limitations of individuals with impairment on to the problems caused by disabling environments, barriers and cultures (Oliver, 2004). Unlike the medical model that based disability on biological factors, the social model says that because of certain disabling environments impairment becomes disability. Oliver (2004) said it is not impairment that is the main cause of social exclusion of disabled people rather, the way society responds to people with impairments. If people with impairments are disabled by society, then the priority is to remove these barriers in order to promote the inclusion of people with impairments. Shakespeare et al, (2002), however, opined that removing environmental obstacles for someone with one impairment may as well generate obstacles for someone with impairment. To them, it is impossible to remove all the obstacles because some of them are in extricate aspects of impairment, not generated by environment. He therefore concluded that there will always be a residuum of people who because of their impairment cannot work, not everyone will be able to achieve inclusion into the economy. While all living beings are impaired (frail, limited, vulnerable, mortal), we are not all oppressed on the basis of this impairment and illness (Shakespeare et al 2002).

Therefore, though this model advocates for provision of enabling environment, it does not deny the fact that impairment is still there. However, it suggests that the priority should be social change and barrier removal. Social model theory in the UK rests on a distinction between impairment, an attribute of the individual body or mind, and disability, a relationship between a person with impairment and society (Shakespeare et al, 2002). Lang et al (2008) opined that the social model disability maintains that rather than focusing on the physical and/or psychological limitations of individuals, the emphasis of the analysis now focuses on the empowerment, social exclusion, choice and human rights. To reiterate the social model disability, impairment dichotomy is a pragmatic one that does not deny that some impairments limit people's ability to function independently. Nor does it deny that people living with disabilities have illnesses at various points in their lives and that appropriate medical interventions are sometimes necessary. How people deal with impairment whatever its cause and severity is determined in many ways by their access to a range of social and material resources. The knowledge of this in this study therefore implies that the impaired do not become disabled until the environment is unsuitable and inconvenient for their existence and productivity.

\section{Methodology}

The study adopted a cross sectional survey design and was complemented with qualitative techniques. Study location was Ibadan metropolis where two local government areas (Ibadan North and Akinyele) were purposively selected by virtue of the fact that they house the highest number of public organisations in Ibadan Metropolis. Using total enumeration techniques, all the public organisations at the local, state and federal levels, in the selected local government areas were included in the study. 
Instruments of data collection were questionnaire (administered on 460 permanent workers selected using Cochran's 1977 formular), In-depth Interviews (conducted with 20 officials in charge of staff matters), Key Informant Interviews (conducted with three (3) officials and five (5) workers living with disabilities). Quantitative data collected were analysed using descriptive statistics, while qualitative data were manually content analysed. Every effort was made to observe ethical issues guiding human subjects in social science research.

\section{Findings And Discussion}

\section{(a) Brief Socio-Demographic Characteristics of Respondents}

Majority of the respondents (54.6\%) were males, while $45.4 \%$ were females. Most of the respondents were in the age bracket of 30-39 years (38.4\%) followed by $24 \%$ who were within the bracket of 40-49 years while the lowest were between the ages of 50-59 (14.4\%), 60 and above represented $1.1 \%$. A total of $48.5 \%$, representing the majority were first degree/HND holders followed by OND/NCE holders (25.5\%) and this suggested that the workforce of the organisations was literate. A total of $74.5 \%$ of the respondents were Christians, while $25.1 \%$ were Muslims. A total of (87.3\%) were of Yoruba ethnic origin, $6.8 \%$ were Igbo and $0.3 \%$ were Hausas; this was expected because the study was conducted in a Yoruba speaking location. About 51.5\% were senior staff, while $48.5 \%$ represented the junior staff.

\section{(b). The Social Exclusion of People with Special Needs}

In describing to what extent and degree people living with disabilities have been excluded both from the work place and the society at large, several variables were put into consideration such as: understanding the meaning of disability, possession of any form of disability, exemption from formal work, the employment of physically challenged persons, perceived reasons for low or absence of this category of people from organisations and the attitudes towards people living with disabilities.

The result on the respondents' perception on the term "disability" shows that majority conceived it to be only physical disability. A few also viewed it as the inability to walk, climb stairs, lift or carry things, but all these still show the physical aspect of disability. This was also supported by the view of others who admitted that hearing loss or deafness, visual difficulties and speech difficulties constitute disability. This still showed the obvious part of disability. The above finding supports the Disability Act (1993) where physical disability was indicated as the most common type of disability. People with special needs who participated in the study demonstrated deeper understanding of the meaning of disability by viewing intellectual disability, mental health and long term illness as disability. The knowledge and perception of disability among study participants who were government officials however differ from the Equality Act 2010 as well as DFID (2007), which described disability as physical or mental condition which has a substantial and long term negative effect on the ability to do normal daily activities. While substantial means more than minor or trivial, long term means 12 months or more. From this definition, both mental and long term illnesses are disabilities so long as they inhibit daily activities. In fact, conditions such as HIV/AIDS, Cancer are covered by the Equality Act 2010 from the point of diagnosis regardless of the symptoms. By implication therefore, it could be inferred that respondents did not have a good understanding of the term disability. If the people and society believe disability is limited to the physical, it implies that other forms like intellectual, mental disabilities will not be treated as disabilities and this may make victims denied of their disability rights as enshrined in various national and international legal instruments.

Figure 1 below provides data on whether respondents had any form of disability on their persons.

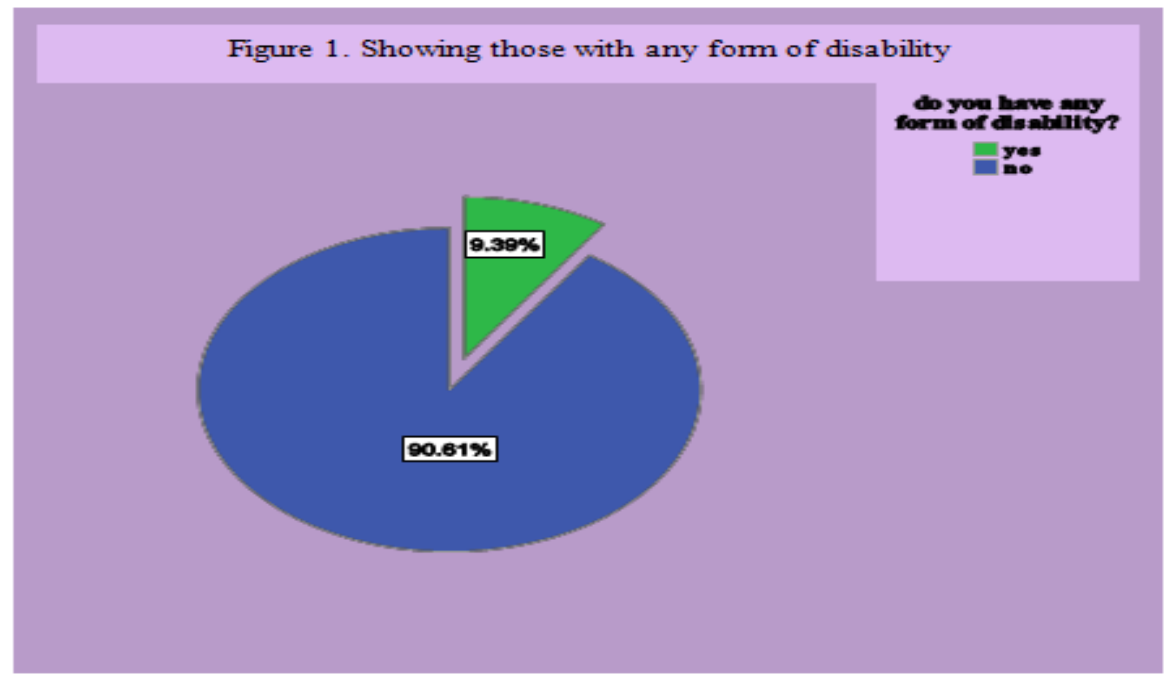

Source: Field Survey 
Results from the figure above show that majority of the study respondents $(90.61 \%)$ claimed they did not have any form of disability in their body, while just a few (9.39\%) indicated otherwise. By implication, those without any form of disability were "able-bodied" constituting the higher percentage while the few were considered to be "disabled", this therefore means there were fewer people living with disabilities in work organisations compared to the "able-bodied". Probing further during IDI sessions, it was discovered that out of the fifteen organisations studied, twelve of the officials in charge of staff matters indicated that they had physically challenged persons in their organisations while three claimed not to have any. Among those who indicated that they had, nine of them indicated further that they had between one and five while others indicated they had more than five but not up to the $10 \%$ of their staff strength as required by the law. By implication therefore, though organisations had employees with special needs, however, they were few compared to the able- bodied and the number of them so employed was very insignificant.

This is one of the responses of an IDI participant;

There are no disabled in this organisation. No formal organisation would want to employ the disabled because every organisation wants to ensure efficiency. The aim of setting up public organisations is to provide service. Is it now someone who is on a wheelchair that you will send to climb?

\section{(IDI/Male/Senior Staff/Federal Agency).}

Probing further on the reasons for the low number of employees living with disabilities, results showed that the few who were recruited was not even as a result of compliance with the laws, but as a result of corporate social responsibility and political factors at play in the Nigerian public service. These findings therefore negate Section 6 of the Nigerian Federal Military Decree 1993, which stipulates that all employers of labour shall reserve for the disabled not less than $10 \%$ of the work force, and that at least $10 \%$ of all fund allocation to training and personal development shall be reserved by employers of labour for the disabled. This thus indicates that there has been poor implementation of laws and policies on disability in public organisations in the study location.

The table below presents data on the perceived reasons for absence or low number of employees in the organisations studied

Table 1 Showing Responses on the perceived reasons for the absence of disabled in Organisations

\begin{tabular}{|l|l|l|l|l|}
\hline Responses & $\begin{array}{l}\text { Frequency } \\
(\mathbf{N = 4 5 8 )}\end{array}$ & Percentages (\%) & Mean & SD \\
\hline $\begin{array}{l}\text { Deliberate disregard for } \\
\text { legislations }\end{array}$ & 98 & 21.4 & 3.50 & 1.20 \\
\hline $\begin{array}{l}\text { The physical environment is } \\
\text { not suitable for the disabled }\end{array}$ & 74 & 16.2 & 3.68 & 1.22 \\
\hline $\begin{array}{l}\text { Perception that people living } \\
\text { with disabilities cannot } \\
\text { perform effectively }\end{array}$ & 75 & 16.4 & 4.33 & 1.91 \\
\hline $\begin{array}{l}\text { There is no work available for } \\
\text { them in your organisation }\end{array}$ & 69 & 15 & 3.52 & 1.18 \\
\hline $\begin{array}{l}\text { There is no supportive } \\
\text { equipment for their } \\
\text { performance }\end{array}$ & 96 & 21 & 3.02 & 1.04 \\
\hline Other reasons & 46 & 10 & & \\
\hline
\end{tabular}

Source: Field Survey

As shown on the table above, a total of $21.4 \%$ indicated that deliberate disregard for available legislations protecting this special class of people was a major factor for their absence or low number in organisations and this was supported by an IDI participant as follows:

Yes there are laws guiding the employment of the disabled, but the implementation is the problem because many organisations in their free will might not employ them

\section{(IDI/Male/Senior Staff/Fed. Agency)}

The IDI excerpt above shows that though there might be laws on ground for the employment of people living with disabilities, particular ministries and organisations would not employ them, this means that there is poor implementation of policies in the country. Organisations generally are mandated to reserve $10 \%$ of their staff strength for the employment of the disabled, yet there is low compliance with such provisions. This supports available research work showing that disregard for legislations is a major factor affecting the success of programmes in Nigeria (Lawal, 2016) 
It was further revealed that there was no supportive equipment in organisations for the effective performance of these special people (21\%) and the physical environment is not suitable for them.

A KII participant revealed that:

Nigeria as a whole is not disability friendly, most work offices are not designed to give people like us free movement. In some cases, no elevators, now walk ways and this limits the movement of disabled people. The working environment in Nigeria is so stereotyped that only physically able-bodied are employed.

\section{(KII/Disabled Male/Tertiary Institution)}

Also, another participant interviewed said that:

There was a time I came with a friend who was on a wheel chair to the education department in this ministry, unfortunately for me, I had to go up to get some files, my friend could not go because there was absolutely no how he could pass freely, that is already excluding those that are disabled even that are not workers

(IDI/Male/Junior Staff/Local Govt Agency)

This means that even if organisations in question want to employ those with disabilities, because there are no encouraging equipment that will aid their performance in the organisation and the way the physical environment has been constructed is not in favour of those with disabilities, they may be discouraged to consider them for employment.

Another reason given for low or complete absence of people with special needs in organisations is the perception that such people cannot perform effectively $(16.4 \%)$. In other words, there is often the stereotype against physically challenged people that they cannot work well and they are limited by their condition. However, this was contradicted by an IDI participant who argued that the physically challenged people are quite hardworking and active. Her words:

The disabled are qualified, more active than the able-bodied. They carry out their duties effectively.

\section{(IDI/Female/Junior Staff/ State Agency)}

In addition, a KII participant opined that;

The disabled are very intelligent and sharp, especially the blind ones, they often excel more than the able bodied in class because they have less concentration and focus on whatever they do. Most of them work as professionals in various fields

(KII/Female/Federal Institution/September, 2016)

These interview responses support ILO report (2010) that employees with disabilities demonstrate high productivity, lower accident rates, and higher job retention compared with the general workforce. It also reported that they contribute to diversity, creativity and workplace morale.

Furthermore, it was indicated that lack of job to be done was another factor accounting for absence or low number of people living with disabilities in the studied organisations (13.9\%). This belief is erroneous as there is no work this category of people can not do. Also, if the need arises, what organisations are expected to do is to carry out job redesigns and provide relevant training to back employees up for effective performance. Job re-design is an excellent tool in human resource management adopted to enhance the performance of workers especially during periods of change in organisations. Other reasons given included the perception that this category of people is not employable and that the social relation culture will not be conducive for them (10\%).

The table below presents data on the social exclusion of people living with disabilities in organisations

Table 2: Opinions of Respondents on the Social Exclusion of people living with disabilities in the workplace.

\begin{tabular}{|c|c|c|c|}
\hline \multicolumn{2}{|l|}{ Category of questions } & $\begin{array}{l}\text { Frequency } \\
\mathrm{N}=\mathbf{4 5 8}\end{array}$ & Percentages (\%) \\
\hline \multirow{3}{*}{$\begin{array}{l}\text { Do you see some jobs as more suitable for } \\
\text { the disabled than the other? }\end{array}$} & Yes & 280 & 61.1 \\
\hline & No & 176 & 38.4 \\
\hline & No response & 2 & .5 \\
\hline \multirow{3}{*}{$\begin{array}{l}\text { Should people with disabilities receive equal } \\
\text { opportunities in terms of employment? }\end{array}$} & Yes & 334 & 72.8 \\
\hline & No & 115 & 25.2 \\
\hline & No response & 9 & 2.0 \\
\hline \multirow{3}{*}{$\begin{array}{l}\text { Should people with disabilities receive same } \\
\text { payments with people "without disabilities" }\end{array}$} & Yes & 362 & 78.9 \\
\hline & No & 89 & 19.5 \\
\hline & No response & 7 & 1.6 \\
\hline
\end{tabular}

Source: Field Survey 
The results gathered from the field survey revealed that most respondents saw some jobs as more suitable for people living with disabilities than others $(61.1 \%)$ while $38.4 \%$ responded that they did not see some jobs as more suitable for this category of workers than others. However, $72.8 \%$ of respondents affirmed that people with disabilities should receive equal opportunities in terms of employment with those that are not disabled, a total of $25.2 \%$ responded in the negative to the question while $2.0 \%$ did not respond to the question. This, therefore, implies that majority of the respondents believed that people living with disabilities once employed should not be excluded in terms of opportunities. This could also be seen as supported by $78.9 \%$ who said people with disabilities should receive same payments with people without disabilities. A total of $19.5 \%$ however did not agree to this, while $1.6 \%$ did not respond. An IDI participant threw further light on the issue as follows:

There are no special benefits for them different from the able-bodied persons, we receive the same thing. In terms of remuneration, they are not specially remunerated or treated. They are not given less.

(IDI/Male/Senior staff/Tertiary Institution/September, 2016)

This response shows a positive attitude by respondents towards the people with special needs and this suggests that they are seen as normal human beings and should therefore be so treated.

The table below presents data on the opinions of respondents on issues of discrimination people with special needs face in organisations.

Table 3: Opinions of Respondents on Discrimination against the Disabled

\begin{tabular}{|l|l|l|l|l|l|l|l|l|}
\hline Variables & SA & A & SD & D & DK & NR & $\begin{array}{l}\text { Mea } \\
\text { n }\end{array}$ & SD \\
\hline $\begin{array}{l}\text { It is society that disables people } \\
\text { by creating barriers }\end{array}$ & $\begin{array}{l}61 \\
(13.3 \%)\end{array}$ & $\begin{array}{l}102 \\
(22.2 \%)\end{array}$ & $\begin{array}{l}42 \\
(9.1 \%)\end{array}$ & $\begin{array}{l}109 \\
(23.7 \%)\end{array}$ & $\begin{array}{l}48 \\
(10.4 \%)\end{array}$ & $\begin{array}{l}96 \\
(20.9 \%)\end{array}$ & 4.12 & .80 \\
\hline $\begin{array}{l}\text { People living with disabilities } \\
\text { should be exempted from } \\
\text { working }\end{array}$ & $\begin{array}{l}32 \\
(2.6 \%)\end{array}$ & $\begin{array}{l}32 \\
(7.0 \%)\end{array}$ & $\begin{array}{l}204 \\
(44.3 \%)\end{array}$ & $\begin{array}{l}189 \\
(41.1 \%)\end{array}$ & $\begin{array}{l}12 \\
(2.6 \%)\end{array}$ & $\begin{array}{l}9 \\
(2.0 \%)\end{array}$ & 3.68 & 1.02 \\
\hline They cannot work effectively & $\begin{array}{l}9 \\
(2.0 \%)\end{array}$ & $\begin{array}{l}101 \\
(22.0 \%)\end{array}$ & $\begin{array}{l}134 \\
(29.1 \%)\end{array}$ & $\begin{array}{l}193 \\
(42.0 \%)\end{array}$ & $\begin{array}{l}12 \\
(2.6 \%)\end{array}$ & $\begin{array}{l}9 \\
(2.0 \%)\end{array}$ & 3.85 & 1.08 \\
\hline $\begin{array}{l}\text { They should be given equal rights } \\
\text { in the workplace }\end{array}$ & $\begin{array}{l}177 \\
(38.5 \%)\end{array}$ & $\begin{array}{l}201 \\
(43.7 \%)\end{array}$ & $\begin{array}{l}19 \\
(4.1 \%)\end{array}$ & $\begin{array}{l}41 \\
(8.9 \%)\end{array}$ & $\begin{array}{l}16 \\
(3.5 \%)\end{array}$ & $\begin{array}{l}4 \\
(0.9 \%)\end{array}$ & 3.41 & 1.06 \\
\hline
\end{tabular}

Source: Field Survey

Most of the respondents (23.7\%) disagreed that society is what disables people by creating barriers. Many of them believed society has no hand in people being disabled. On the other hand, $22.2 \%$ agreed that it is society that disables, $13.3 \%$ strongly agreed while $9.1 \%$ strongly disagreed. A total of $10.4 \%$ said they didn't know and $20.9 \%$ did not respond to the question. The views of the simple majority contradicts the existing literature and the social model of disability theory and it also suggests that it may be due to inadequate knowledge of respondents on the issue of disability. In contrary, Oliver (1996), Shakespeare (2002), Lang (2008) declared that it is society that disables impaired people. In other words, though impairment may be in existence however by creating environmental and attitudinal barriers, the society inhibits the abilities of impaired people. By implication, through its construction of the environment, the society limits people with disabilities from carrying out essentialities. Qualitative data further supported this issue:

A KII participant revealed that:

Society handicaps impaired people, even though some people handicap themselves, to a large extent, the society also handicaps. The attitude the disabled get when they go for employment is enough to handicap them, even though some of them are so vast and do excellently well. A better construction of sentence is society handicap not disables.

\section{(KII/Disabled Male/Tertiary Institution)}

However, an IDI participant opined that:

The society does not disable, rather they might just add to it, but it doesn't remove the fact that the disability is still there.

\section{(IDI/Male/Senior Staff/State Agency)}

Furthermore, from the table majority $(44.3 \%$ and $41.1 \%)$ strongly disagreed and disagreed respectively that people with special needs should be exempted from working. A few of the respondents (7.0\% and $2.6 \%)$ agreed and strongly agreed respectively that disabled should be exempted from working. In addition, $42.0 \%$ and $29.1 \%$ disagreed and strongly disagreed respectively constituting the majority that people with special needs cannot work effectively. While 22.0 agreed to it, $2.0 \%$ strongly agreed. $2.6 \%$ and $2.0 \%$ did not know and did not respond to the question respectively. 
Also, majority of respondents $(43.7 \%$ and $38.5 \%)$ agreed and strongly agreed respectively that people with special needs should be given equal rights in the workplace. Few $8.9 \%$ and $4.1 \%$ disagreed and strongly disagreed it, $3.5 \%$ and $0.9 \%$ did not know and did not respond to the question.

This therefore implies that there is a positive attitude from the respondents towards people living with special needs. Implying from the figures stated earlier, it is seen that respondents said that people living with disabilities should not be exempted from working, they can work effectively and also they should be given equal rights. This shows respondents feel that this category of persons should not be socially excluded from the society. These individual opinions suggest social inclusion and non-discrimination against people with special needs, but they negate practices in organisations. Organisations may not openly discriminate against them but the unwillingness to employ them, non provision of adaptive equipment and conducive working environments plus non- compliance with statutory provisions are indirect ways of discrimination and social exclusion of this category of people in the society

\section{(c). Interpersonal Relationships with disabled persons in the workplace}

The way "able-bodied" workers relate with their disabled co-workers goes a long way in determining the discrimination and exclusion of the people with special needs both in the workplace and in the society at large. To address this objective, the following variables were taken into consideration:

How would respondents feel about having a work colleague living with special needs?; What would make respondents feel uncomfortable working with a colleague living with special needs?

Figure 2 below presents data on how respondents will feel about having people with special needs as work colleagues:

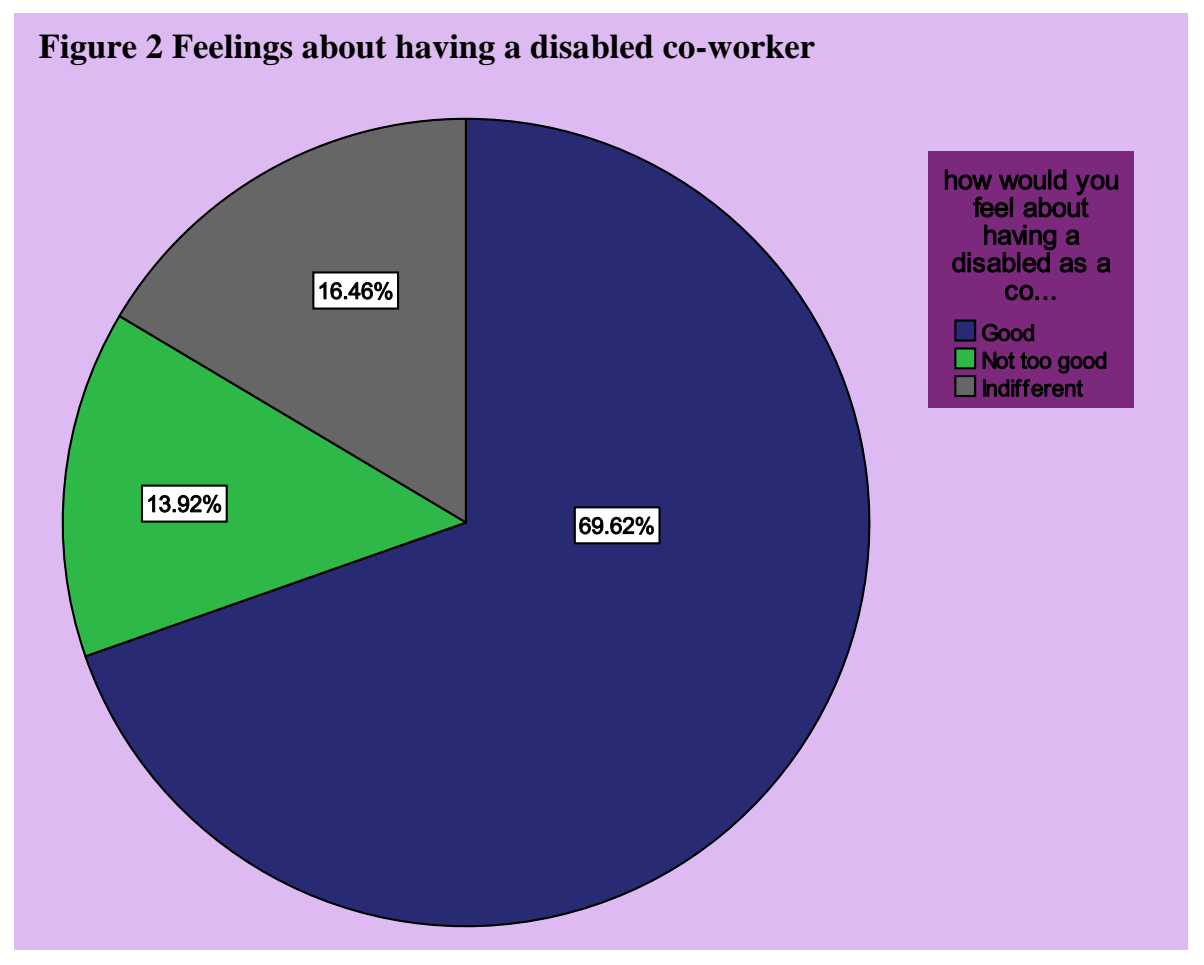

Source: Field Survey

The results gathered in examining how workers will feel when they have people living with disabilities of any form as colleagues or co-workers in the organisation show that majority $(69.6 \%)$ actually revealed that they will feel good about having a co-worker in that condition. However, $16.4 \%$ indicated that they will be quite indifferent about it as it will not demand any special attention from them, in other words, whether there such co-workers are disabled or not, they will not be obligated to their condition. On the other hand, some (13.9\%) that actually formed the minority said they will not feel too good about it. This could however be as a result of several reasons which may include; the type of disabilities in question, difficulty in relating with the disabled and issue of pity and compassion as revealed by IDI respondents as follows:

An IDI participant in his view opined:

How I relate with the disabled depends on the nature or type of the symptoms displayed by the disabled person.

(IDI/Male/Junior Staff/Local Govt. Agency) 
A KII participant who is physically disabled said that:

I don't like the attitude of people here, but still I have to accommodate them, I'm still amidst them. (KII/Disabled Male/Senior staff/ Tertiary Institution)

From the IDI excerpts above, respondents were likely not to relate well with disabled co-worker more so when the form of disability is obvious. A physically challenged employee that was interviewed however revealed that the attitudes of co-workers were not encouraging but because he has no choice, he had to put up with them. This supports Lang and Upah (2008) who said the attitudes of the public stand as a barrier such that they lack understanding of disability issues thereby perceiving disability to be that of charity and/or welfare and not in terms of human rights.

The table below presents data on what would make employees feel uncomfortable working with a co-employee who is physically challenged.

Table 4: Multiple Responses on what would make Respondents Uncomfortable with having a Disabled Co-worker

\begin{tabular}{|l|l|l|}
\hline Responses & Frequency & Percentage \\
\hline Not knowing how to relate with them & 108 & 15.2 \\
\hline Worries about infections & 51 & 7.2 \\
\hline Not capable of work & 77 & 10.8 \\
\hline $\begin{array}{l}\text { They will be better off in sheltered } \\
\text { employment }\end{array}$ & 36 & 5.1 \\
\hline More work for self or other work colleagues & 54 & 7.6 \\
\hline $\begin{array}{l}\text { Having to make accommodations around the } \\
\text { workplace }\end{array}$ & 126 & 17.7 \\
\hline Feel pity for them & 206 & 29.0 \\
\hline Nothing & 52 & 7.3 \\
\hline
\end{tabular}

Source: Field Survey

The reasons why workers would feel uncomfortable having a physically challenged as a colleague are numerous. These reasons however could inhibit interactions with them. A total of $15.2 \%$ said they were likely not to know how to relate with the person. This could be because workers would want to know the right words to say so as not to hurt them. Just a few $5.1 \%, 7.2 \%, 7.6 \%$ revealed their own reason behind being uncomfortable with physically challenged colleagues are; they are better off in sheltered employment, worries about infection and more work for self or other colleagues respectively. However, some $(17.7 \%)$ opined that the problem was the need to make accommodations around the workplace. The majority (29.0\%) opined that they would feel pity for them. This can be explained further by saying that most often than not disability is seen in a pitiable condition and regarded with charity mentality. Also, some others (7.3\%) said nothing would make them feel uncomfortable about having physically challenged as a work colleague. The majority position here is however interesting as it suggests a positive attitude towards people with special needs in organisations.

Findings from this study justify the theoretical framework adopted for this study, that it is not impairment that disables people; rather it is the social construction and the attitude of the people and organisations, and lack of compliance with existing legislations that actually disable people and render them unproductive. The model explains that the attitudes of people in the society coupled with the environment disables impaired people. The attitudes from the society about this category of people could make them lose confidence in themselves such that the working environment is not conducive for them. The model is not denying the fact that the impairment is still there no matter the adjustment made by the society, however it advocates for a change of discriminatory attitude by the society.

\section{Conclusion and Recommendations}

From this study, people living with special needs continue to experience discriminations in terms of employment opportunities into formal organisations as well as in terms of unconducive work environment for the privileged few in organisations. This discrimination is pronounced at the organisational level, and non-adherence to existing legislations was a major factor responsible for this situation. But in terms of inter-personal relationships, attitude towards this special class of people was seen as more encouraging. Most workers had positive attitude to them, are willing to accept them as work colleagues, and see them as persons with potentials capable of contributing to the development and growth of organisations. 
Governments at all levels should therefore ensure compliance with available legislations to ensure effective inclusion of people with special needs so that their rights could be fully protected in public organisations in Nigeria. Organisations are also enjoined to ensure their inclusion by making the workplace more conducive for them and giving them equal opportunities in the areas of employment, work benefits and other protections as stipulated by relevant legislations

\section{References}

Asiwe C.C. \& Omiegbe O., 2014.Legal and Ethical Issues of Persons with Special Needs in Nigeria.Educational Research and Reviews. Vol. 9, Pp 516 - 522.

Barnes, C. 1991.Disabled People and Discrimination in Britain: The Case for Anti Discrimination Legislation. London: Hurst \&Co.in association with the British Council of Organisations of Disabled People Berkeley, California: University of California Press

Carol, G., 2002. Barriers to Employment for Disabled People. London.

Coleman, N., Sykes W. \& Carola G. 2013, Barriers to Employment and Unfair Treatment at Work: A Quantitative Analysis of Disabled People's Experiences. No 88. Independent Social Research, Equality and Human Rights Commission. Manchester, United Kingdom.

DFID Nigeria. 2007. State Partnership for Accountability, Responsiveness and Capability -Project Memorandum, DFID, Abuja.

DFID. 2005. Reducing Poverty by Tackling Social Exclusion: A DFID Policy Paper. Pp 3-19

Duffy K.1995.Social Exclusion and Human Dignity in Europe, Council of Europe.

Hall, S. 2009. The Social Inclusion of People with Disabilities: A Qualitative Meta-analysis. Journal of Ethnographic \& Qualitative Research, Vol. 3, 162-173

Haralambos M.\& Holborn M. 2008. Sociology, (7 ${ }^{\text {th }}$ edition). London. Harper Collins Publisher Ltd.

International Labour Organisation. 2010. Disability in the Workplace: Company Practices. Bureau for Employers'

Activities and Skills and Employability Department. Geneva. No 3

Klasen S. 1998. Social Exclusion and Children in OECD countries: Some Conceptual Issues.

Lang, R. \&Upah L. 2008, Scoping Study: Disability Issues in Nigeria. Commissioned by DFID. Pp 6-51

Lawal, S.A., 2016, Issues of Policy Implementation in Nigeria, Akure: P-Kay publishers

Oliver M. 2004. Implementing the Social Model of Disability: Theory and Research, Disability Press, Pp18-31

Oliver, M. 1996. Understanding disability: from theory to practice. Basingstoke: Macmillan

Rezaul M. I. \& Sharmin K. 2011, Social Exclusion in Non- Government Organisations (NGOs) Activities in Bangladesh, Sociology Mind, Vol.1-2, Pp. 36-44.

Rezaul M. I. 2015, Rights of the People with Disabilities and Social Exclusion in Malaysia. International Journal of Social Science and Humanity, Vol. 5, No 2, Pp 171-176.

Section 23 (1) and section 2 (3)

Shakespeare, T. \& Watson, N. 2002: The Social Model of Disability: An Outdated Ideology, Research in Social Science and Disability, Vol. 2, Pp 9-28

Silver H. 2007. Social Exclusion: Comparative Analysis of Europe and Middle East Youth, Middle East Youth Working Paper

UNICEF 2006. Violence against Children with disabilities: UN Secretary General'sReport on Violence against Children. Thematic Group on Violence against Childrenwith disabilities. Geneva: ILO.

World Health Organisation.1980: International Classification of Impairments, Disabilities and Handicaps. Geneva: World Health Organisation.

\section{Legal Instruments}

Constitution of the Federal Republic of Nigeria. 1999.

Nigerians with Disability Act 1993

Special Peoples Law (SPL), 2011, The Special Peoples Law, Nigeria: Lagos State Government.

The Convention on the Rights of Persons with Disability, (CRPD), 2006

The Employment Equality Act 2004

The Equality Act, 1993

The Disability Act, 1995

The NSW Anti-Discrimination Act, 1977

The Work Environment Act, 2013

United Nations. 2008. Convention on the Rights of Persons with Disabilities.

United Nations. 2014. Convention on the Rights of Persons with Disabilities. 